\title{
Study of the antiproliferative potential of seed extracts from Northeastern Brazilian plants
}

\author{
PAULO MICHEL P. FERREIRA ${ }^{1}$, DAVI F. FARIAS ${ }^{2}$, MARTÔNIO P. VIANA ${ }^{2}$, \\ TEREZINHA M. SOUZA ${ }^{2}$, ILKA M. VASCONCELOS ${ }^{3}$, BRUNO M. SOARES ${ }^{4}$, CLÁUdIA PESSOA ${ }^{4}$, \\ LETÍCIA V. COSTA-LOTUFO ${ }^{4}$, MANOEL O. MORAES ${ }^{4}$ and ANA F.U. CARVALHO ${ }^{2}$ \\ ${ }^{1}$ Departamento de Ciências Biológicas, Campus Senador Helvídio Nunes de Barros, Universidade Federal do Piauí, \\ Rua Cícero Duarte, 905, 64600-000 Picos, PI, Brasil \\ ${ }^{2}$ Departamento de Biologia, Universidade Federal do Ceará, Av. Mister Hall, s/n, 60455-970 Fortaleza, CE, Brasil \\ ${ }^{3}$ Departamento de Bioquímica e Biologia Molecular, Universidade Federal do Ceará, \\ Av. Mister Hall s/n, 60455-970 Fortaleza, CE, Brasil \\ ${ }^{4}$ Departamento de Fisiologia e Farmacologia, Faculdade de Medicina, Universidade Federal do Ceará, \\ Rua Cel. Nunes de Melo, 1127, 60430-270, Fortaleza, CE, Brasil \\ Manuscript received on August 14, 2009; accepted for publication on March 4, 2011
}

\begin{abstract}
This study assessed the antiproliferative and cytotoxic potential against tumor lines of ethanolic seed extracts of 21 plant species belonging to different families from Northeastern Brazil. In addition, some underlying mechanisms involved in this cytotoxicity were also investigated. Among the 21 extracts tested, the MTT assay after $72 \mathrm{~h}$ of incubation demonstrated that only the ethanolic extract obtained from Myracrodruon urundeuva seeds (EEMUS), which has steroids, alkaloids and phenols, showed in vitro cytotoxic activity against human cancer cells, being 2-fold more active on leukemia HL-60 line [ $\mathrm{IC}_{50}$ value of $12.5(9.5-16.7) \mu \mathrm{g} / \mathrm{mL}$ ] than on glioblastoma SF-295 [IC 50 of 25.1 $(17.3-36.3) \mu \mathrm{g} / \mathrm{mL}$ ] and Sarcoma 180 cells [ $\mathrm{IC}_{50}$ of $\left.38.1(33.5-43.4) \mu \mathrm{g} / \mathrm{mL}\right]$. After $72 \mathrm{~h}$ exposure, flow cytometric and morphological analyses of HL-60-treated cells showed that EEMUS caused decrease in cell number, volume and viability as well as internucleosomal DNA fragmentation in a dose-dependent way, suggesting that the EEMUS triggers apoptotic pathways of cell death.
\end{abstract}

Key words: antiproliferative potential, Northeastern Brazilian plants, Myracrodruon urundeuva, sarcoma 180 tumor, seed extracts.

\section{INTRODUCTION}

There is considerable scientific and commercial interest in discovering new anticancer agents from natural product sources (Kinghorn et al. 2003). The potential of using natural products as anticancer agents was recognized in the 1950s by the U.S. National Cancer Institute (NCI) and since then several studies have given valuable contributions to the discovery of new naturally occurring anticancer agents. In the 1980s, the development of new screening technologies led the research for new anticancer agents in plants and other organisms, focus-

Correspondence to: Dr. Paulo Michel Pinheiro Ferreira E-mail: pmifepe@yahoo.com.br/pmpf@ufpi.edu.br ing on the tropical and sub-tropical regions of the world (Cragg and Newman 2005).

Brazil possesses the largest diversity of plant species in the world, but less than $10 \%$ have been evaluated with respect to their biological characteristics, and fewer than $5 \%$ have been subjected to detailed phytochemical studies (Luna et al. 2005). In Northeastern Brazil, a region with approximately $1,539,000 \mathrm{~km}^{2}$, with warm and dry climate, grows the peculiar xerophitic "Caatinga" vegetation (dry land vegetation). In Caatinga flora, there are almost 1000 vascular plant species and due to the extreme climate conditions most species are endemic (Lemos and Rodal 2002, Sampaio 2002, 
Santos et al. 2008). Despite this great biodiversity, Northeastern Brazilian plants are relatively underexploited with regard to discoveries of active biological substances (Luna et al. 2005).

Seeds, especially from legumes, are recognized by their nutritional value, rich in proteins, carbohydrates and oil, though they are not merely a site to accumulate organic materials. They need physical and chemical mechanisms for protection and/or defense for the developing embryo. The compounds involved in chemical defense include lectins, protease and amylase inhibitors, toxins and low molecular mass compounds (secondary metabolites) (Xavier-Filho 1993, Sampaio et al. 1992, Ferreira et al. 2009). According to some reports many seeds and other parts from Northeastern Brazilian plants are exploited in popular medicine and many of these present important pharmacological properties. The ethnomedical data and some pharmacological activities of the studied plants are shown in Table I. Nevertheless, these plants, especially their seeds, are scarcely studied concerning cytotoxicity on tumor cell strains. Thus, the aim of the present study was to assess the antiproliferative potential of ethanolic seed extracts of twenty-one plant species belonging to different families from Northeastern Brazil on tumor cells and study some underlying mechanisms involved in this cytotoxicity.

\section{MATERIALS AND METHODS}

ANIMALS

Adult Swiss mice (Mus musculus Linnaeus, 1758) were obtained from the animal facilities of the Universidade Federal do Ceará, Fortaleza, Brazil. They were kept in well ventilated cages under standard conditions of light (12 $\mathrm{h}$ with alternative day and night cycles) and temperature $\left(27 \pm 2^{\circ} \mathrm{C}\right)$ and housed with access to commercial rodent stock diet (Nutrilabor, Campinas, Brazil). All procedures are in accordance with COBEA (Colégio Brasileiro de Experimentação Animal) (Process no. 102/2007) and International Standard on the care and use of experimental animals (EEC Directive of 1986, 86/609/EEC).

\section{Plant MATERial}

Harvest of the plant materials was carried out in three different localities in Ceará State, Northeastern Brazil: the Caatinga forest (dry land vegetation), Araripe National Forest (rain forest), and in the coastal zone. Mature wild seeds (at least $500 \mathrm{~g}$ ) of each plant species were collected during the dry period (from January 2005 to November 2007), with help of native people. Plants were identified and voucher specimens were deposited at Herbarium Prisco Bezerra - EAC, Universidade Federal do Ceará (Fortaleza, Ceará, Brazil). Table I described all the species studied in this work, their voucher numbers, common names, harvest data and medicinal applications.

\section{Preparation of CRUde EXTRACTS}

Seeds of freshly collected plant material were separated, immediately air dried and finally ground in a laboratory mill (Quimis, Campinas, São Paulo, Brazil) to a moderately-fine powder (mesh size $0.5 \mathrm{~mm}$ ). Powdered material (500 g) was submitted to extraction with $99 \%$ ethanol $(1.5 \mathrm{~L})$ at room temperature $\left(25-27^{\circ} \mathrm{C}\right)$ for 3 days and filtered. The residue was re-extracted twice in a similar manner. The extracts were evaporated and bulked under reduced pressure in a rotary evaporator. Crude extracts were stored in a freezer at $-20^{\circ} \mathrm{C}$ until required. A stock solution containing $10 \mathrm{mg} / \mathrm{mL}$ of each crude extract was prepared by suspending $10 \mathrm{mg}$ of extract in $1 \mathrm{~mL}$ of sterile dimethylsulphoxide (DMSO, Sigma Aldrich) (Torres et al. 2005, Costa et al. 2008, Buriol et al. 2009, Magalhães et al. 2010), mixed by sonication (Bandelin, model RK-100, Berlin, GER) for $20 \mathrm{~min}$

\section{Cytotoxicity Against Human Tumor Cell Lines}

The antiproliferative potential of the seed extracts was evaluated by the MTT assay (Mosmann 1983) against 4 human tumor cell lines: HL-60 (leukemia), SF-295 (glioblastoma), HCT-8 (colon) and MDA/MB-435 (melanoma), all obtained from the National Cancer Institute (Bethesda, MD, USA). All cell lines were maintained in RPMI 1640 medium supplemented with 10\% fetal bovine serum, $2 \mathrm{mM}$ glutamine, $100 \mathrm{U} / \mathrm{mL}$ penincillin and $100 \mu \mathrm{g} / \mathrm{mL}$ streptomycin, at $37^{\circ} \mathrm{C}$ with $5 \%$ $\mathrm{CO}_{2}$. Tumor cell growth was quantified by the ability of living cells to reduce the yellow dye 3-(4,5-dimethyl-2thiazolyl)-2,5-diphenyl-2 $H$-tetrazolium bromide (MTT) to a purple formazan product. Briefly, cells were plated in 96-well plates $\left[0.7 \times 10^{5}\right.$ cells/well for adherent cells 
TABLE I

Plant species employed in this study and some ethnobotanical uses and pharmacological activities.

\begin{tabular}{|c|c|c|c|}
\hline $\begin{array}{l}\text { FAMILY } \\
\text { Botanical name } \\
\text { Common name } \\
\text { [Locality: date of collect] } \\
\text { Voucher number }\end{array}$ & Yield $(\%)$ & Traditional medicinal use & Pharmacological activities \\
\hline $\begin{array}{l}\text { ANACARDIACEAE } \\
\text { Myracrodruon urundeuva Fr. All. } \\
\text { Aroeira-do-sertão } \\
\text { [Araripe National Forest: 01/07] } \\
34,865\end{array}$ & 25.2 & $\begin{array}{l}\text { Cutaneous and gynecological } \\
\text { affections, kidney and respiratory } \\
\text { problems; anti-inflammatory, } \\
\text { antiulcer, healing (Sousa et } \\
\text { al. 2004); antimicrobial (Matos } \\
\text { 2000); analgesic, anti-diarrheal } \\
\text { (Maia 2004) }\end{array}$ & $\begin{array}{l}\text { Anti-colitis (Rodrigues et al. } \\
\text { 2002); anti-inflammatory, } \\
\text { analgesic (Viana et al. 2003); } \\
\text { anti-ulcer (Souza et al. 2007); } \\
\text { anti-periodontitis (Botelho et } \\
\text { al. 2007) }\end{array}$ \\
\hline $\begin{array}{l}\text { Schinopsis brasiliensis Engl. } \\
\text { Braúna } \\
\text { [Araripe National Forest: 01/07] } \\
35,643\end{array}$ & 2.88 & $\begin{array}{l}\text { Cause nervosism and hysteria, } \\
\text { analgesic (Maia 2004) }\end{array}$ & Not described \\
\hline $\begin{array}{l}\text { CARYOCARACEAE } \\
\text { Caryocar coriaceum Wittm. } \\
\text { Pequi } \\
\text { [Araripe National Forest: 09/05] } \\
35.231\end{array}$ & 23.1 & Not described & Not described \\
\hline $\begin{array}{l}\text { CHRYSOBALANACEAE } \\
\text { Licania tomentosa Benth. } \\
\text { Oiti } \\
\text { [Coast zone: } 01 / 08] \\
40,215\end{array}$ & 4.4 & Not described & $\begin{array}{l}\text { Anti-viral (Miranda et al. 2002); } \\
\text { cytotoxic (Fernandes et al. 2003) }\end{array}$ \\
\hline $\begin{array}{l}\text { Licania rigida Benth. } \\
\text { Oiticica } \\
\text { [Coastal zone: } 12 / 07] \\
40,216\end{array}$ & 28.1 & $\begin{array}{l}\text { Used to treat diabetes, } \\
\text { anti-inflammatory (Maia 2004) }\end{array}$ & Not described \\
\hline $\begin{array}{l}\text { CONNARACEAE } \\
\text { Connarus detersus } \text { Planch. } \\
\text { Cabelo-de-negro } \\
\text { [Araripe National Forest: 01/05] } \\
34,733\end{array}$ & 28.5 & Not described & Not described \\
\hline $\begin{array}{l}\text { FABACEAE } \\
\text { Adenanthera pavonina L. } \\
\text { Falso-sândalo } \\
\text { [Coastal zone: } 08 / 07] \\
38,389\end{array}$ & 6.12 & Not described & $\begin{array}{l}\text { Anti-inflammatory, analgesic } \\
\text { (Olajide et al. 2004) }\end{array}$ \\
\hline $\begin{array}{l}\text { Amburana cearensis (All.) A.C. Smith } \\
\text { Cumaru, amburana } \\
\text { [Caatinga forest: } 11 / 07] \\
39,618\end{array}$ & 6.43 & $\begin{array}{l}\text { To treat rheumatism, cold, } \\
\text { synusites, antispasmodic, healing, } \\
\text { anti-inflammatory (Maia 2004, } \\
\text { Sousa et al. 2004) }\end{array}$ & $\begin{array}{l}\text { Hepatoprotection (Leal et al. } \\
\text { 2008); broncodilatation (Leal et al. } \\
\text { 2006); neuroprotection (Leal et } \\
\text { al. 2005); cytotoxic (Costa-Lotufo } \\
\text { et al. 2003); anti-inflammatory, } \\
\text { muscle relaxant (Leal et al. 2003) }\end{array}$ \\
\hline $\begin{array}{l}\text { Anadenanthera macrocarpa (Benth.) Brenan } \\
\text { Angico vermelho } \\
\text { [Caatinga forest: 07/05] } \\
38,697\end{array}$ & 9.35 & $\begin{array}{l}\text { To treat respiratory diseases, } \\
\text { gonorrhea, diarrhea; adstringent, } \\
\text { antirheumatic, anti-inflammatory, } \\
\text { sedative, healing (Maia 2004) }\end{array}$ & $\begin{array}{l}\text { Antioxidant (Desmarchelier } \\
\text { et al. 1999) }\end{array}$ \\
\hline $\begin{array}{l}\text { Dioclea megacarpa Rolfe } \\
\text { Mucunã, olho-de-boi } \\
\text { [Araripe National Forest: 01/05] } \\
38,110\end{array}$ & 2.40 & Not described & Not described \\
\hline
\end{tabular}


TABLE I (continuation)

\begin{tabular}{|c|c|c|c|}
\hline $\begin{array}{l}\text { FAMILY } \\
\text { Botanical name } \\
\text { Common name } \\
\text { [Locality: date of collect] } \\
\text { Voucher number }\end{array}$ & Yield (\%) & Traditional medicinal use & Pharmacological activities \\
\hline $\begin{array}{l}\text { FABACEAE } \\
\text { Enterolobium contortisiliquum (Vell.) Morong } \\
\text { Orelha-de-negro } \\
\text { [Araripe National Forest: 09/05] } \\
38,115\end{array}$ & 2.80 & Not described & $\begin{array}{l}\text { Antimicrobial (Shahat et al. 2008); } \\
\text { cytotoxic (Mimaki et al. 2003); } \\
\text { anticoagulant (Sampaio et al. } \\
\text { 1992); pro-inflammatory (Castro- } \\
\text { Faria-Neto et al. 1991); hemolytic } \\
\text { (De Sousa and Morhy 1989) }\end{array}$ \\
\hline $\begin{array}{l}\text { Hymenaea courbaril L. } \\
\text { Jatobá } \\
\text { [Araripe National Forest: 01/05] } \\
38,108\end{array}$ & 9.50 & Not described & $\begin{array}{l}\text { 5-lipoxygenase inhibition (Braga } \\
\text { et al. 2000); antiplasmodial } \\
\text { (Köhler et al. 2002) }\end{array}$ \\
\hline $\begin{array}{l}\text { Lonchocarpus sericeus (Poiret) Kunth } \\
\text { Ingá } \\
\text { [Coast Zone: } 10 / 06] \\
39,615\end{array}$ & 10.60 & Not described & $\begin{array}{l}\text { Anti-inflammatory, antimicrobial } \\
\text { (Alencar et al. 2005); cytotoxic } \\
\text { (Cunha et al. 2003) }\end{array}$ \\
\hline $\begin{array}{l}\text { Luetzelburgia auriculata (Allemao) Ducke } \\
\text { Pau-mocó } \\
\text { [Caatinga Forest: 11/06] } \\
40,365\end{array}$ & 8.40 & Not described & Not described \\
\hline $\begin{array}{l}\text { Parkia platycephala Benth. } \\
\text { Visgueiro } \\
\text { [Araripe National Forest: 01/06] } \\
38,109\end{array}$ & 17.50 & Not described & Not described \\
\hline $\begin{array}{l}\text { Piptadenia moniliformis Benth. } \\
\text { Catanduva } \\
\text { [Caatinga Forest: 01/05] } \\
35,974\end{array}$ & 6.18 & Not described & Not described \\
\hline $\begin{array}{l}\text { Senna obtusifolia } \text { (L.) H.S.Irwin \& Barneby } \\
\text { Mata pasto } \\
\text { [Caatinga Forest: 07/05] } \\
39,320\end{array}$ & 5.70 & Not described & Not described \\
\hline $\begin{array}{l}\text { POLYGONACEAE } \\
\text { Triplaris gardneriana Wedd } \\
\text { Pajeú } \\
\text { [Caatinga Forest: } 11 / 06] \\
39,600\end{array}$ & 26.0 & Not described & Not described \\
\hline $\begin{array}{l}\text { RHAMNACEAE } \\
\text { Ziziphus joazeiro Mart } \\
\text { Juá, juazeiro } \\
\text { [Coast Zone: } 03 / 08 \text { ] } \\
40,366\end{array}$ & 7.22 & $\begin{array}{l}\text { Expectorant, antipyretic, used to } \\
\text { treat skin, blood, stomach and } \\
\text { liver diseases, ulcer, antimicrobial } \\
\text { (Maia 2004) }\end{array}$ & $\begin{array}{l}\text { Antifungal (Cruz et al. 2007); } \\
\text { antioxidant, antibacterial (Alviano } \\
\text { et al. 2008) }\end{array}$ \\
\hline $\begin{array}{l}\text { SAPINDACEAE } \\
\text { Talisia esculenta (A. St-Hill) Radlk } \\
\text { Pitomba } \\
\text { [Coast Zone: } 03 / 08 \text { ] } \\
40,685\end{array}$ & 1.50 & Not described & Not described \\
\hline $\begin{array}{l}\text { Sapindus saponaria } \mathrm{L} . \\
\text { Sabonete } \\
\text { [Caatinga Forest: } 11 / 06 \text { ] } \\
39,601\end{array}$ & 10.7 & Not described & $\begin{array}{l}\text { Antifungal (Tsuzuki et al. 2007); } \\
\text { antiulcer (Albiero et al. 2008) }\end{array}$ \\
\hline
\end{tabular}


(SF295, MDA/MB-435, HCT-8) and $0.3 \times 10^{5}$ cells/well for suspended cells (HL-60)] and extracts $(50 \mu \mathrm{g} / \mathrm{mL})$ were added to each well. After $72 \mathrm{~h}$ of incubation, the supernatant was replaced by fresh medium containing MTT $(0.5 \mathrm{mg} / \mathrm{mL})$, the formazan product was dissolved in $150 \mu \mathrm{L}$ DMSO and absorbance was measured at $595 \mathrm{~nm}$ (DTX 880 Multimode Detector, Beckman Coulter). Doxorubicin (0.3 $\mu \mathrm{g} / \mathrm{mL}$, Sigma Aldrich) was used as positive control.

\section{HEMATOXYLIN-EOSIN STAIN}

HL-60 cells treated or untreated with the ethanolic extract of Myracrodruon urundeuva seeds (EEMUS) $(6.25,12.5$ and $25 \mu \mathrm{g} / \mathrm{mL})$ were examined for morphological changes by light microscopy (Metrimpex Hungary/PZO-Labimex Modelo Studar lab) after 72 h exposure. Cells were harvested, transferred to cytospin slides, fixed with methanol for $1 \mathrm{~min}$ and stained with Hematoxylin-Eosin (H\&E). Doxorubicin $(0.3 \mu \mathrm{g} / \mathrm{mL})$ was used as positive control.

\section{Flow Cytometry Analyses}

All cytometry analyses were determined in a Guava EasyCyte Mine (Guava Express Plus software). Five thousand events were evaluated per experiment and cellular debris was omitted from the analysis. Experiments were performed in triplicate using HL-60 cells and analyzed after $72 \mathrm{~h}$ of incubation with EEMUS (6.25, 12.5 and $25 \mu \mathrm{g} / \mathrm{mL}$ ).

\section{Cell number and membrane integrity}

Cell membrane integrity was evaluated by the exclusion of propidium iodide $(50 \mu \mathrm{g} / \mathrm{mL}$, Sigma Aldrich Co. St. Louis, MO/USA). Briefly, $100 \mu \mathrm{L}$ of treated and untreated cells were incubated with propidium iodide $(50 \mu \mathrm{g} / \mathrm{mL})$. The cells were then incubated for $5 \mathrm{~min}$. Fluorescence was measured and cell number and membrane integrity were determined (Darzynkiewicz et al. 1992).

\section{Internucleosomal DNA fragmentation}

Internucleosomal DNA fragmentation was evaluated by the incorporation of propidium iodide $(50 \mu \mathrm{g} / \mathrm{mL})$. Briefly, HL-60 cells were treated and then incubated at $25^{\circ} \mathrm{C}$ for $30 \mathrm{~min}$, in the dark, in a lysis solution containing $0.1 \%$ citrate, $0.1 \%$ Triton X-100 and $50 \mu \mathrm{g} / \mathrm{mL}$ propidium iodide. Fluorescence was measured and DNA fragmentation was analyzed according to Nicoletti et al. (1991).

\section{Measurement of mitochondrial transmembrane potential}

Mitochondrial transmembrane potential was determined by the retention of rhodamine 123 dye. Aliquots removed from wells were incubated with $200 \mu \mathrm{L}$ of rhodamine 123 in the dark for $15 \mathrm{~min}$ and centrifuged at $2000 \mathrm{rpm} / 5 \mathrm{~min}$. Subsequently, cells were harvested and incubated in PBS solution for $30 \mathrm{~min}$. at $25^{\circ} \mathrm{C}$ (CuryBoaventura et al. 2003).

\section{In vitro ANTIPROLIFERATIVE ACTIVITY ON SARCOMA 180 CELLS}

In order to predict activity of EEMUS towards an in vivo cancer model, ascite-bearing female mice between 7 and 9 days postinoculation were sacrificed by cervical dislocation and a suspension of Sarcoma 180 cells was harvested from the intraperitoneal cavity under aseptic conditions. The suspension was centrifuged at $500 \mathrm{Xg}$ for $5 \mathrm{~min}$ to obtain a cell pellet and washed three times with RPMI medium. Cell concentration was adjusted to $0.5 \times 10^{6}$ cells $/ \mathrm{mL}$ in RPMI 1640 medium supplemented with $20 \%$ fetal bovine serum, $2 \mathrm{mM}$ glutamine, $100 \mathrm{U} / \mathrm{mL}$ penincillin and $100 \mu \mathrm{g} / \mathrm{mL}$ streptomycin, plated in a 96-well plate and incubated with increasing concentrations of EEMUS (1.56-100 $\mu \mathrm{g} / \mathrm{mL})$. Cell proliferation was determined by the Alamar Blue assay after $72 \mathrm{~h}$ extract exposure according to Ferreira et al. (2010), with some modifications. Eight hours before the end of the incubation, $10 \mu \mathrm{L}$ of stock solution $(0.312 \mathrm{mg} / \mathrm{mL})$ of Alamar Blue (Resazurin, Sigma Aldrich Co) were added to each well. The absorbance was measured at $570 \mathrm{~nm}$ and $595 \mathrm{~nm}$ using a multiplate reader (DTX 880 Multimode Detector) and the drug effect was quantified as the percentage of the control. Doxorubicin $(0.3 \mu \mathrm{g} / \mathrm{mL})$ was used as positive control.

\section{Phytochemical Study of Ethanolic Extracts}

Phytochemical tests to detect the presence of secondary metabolites in EEMUS such as phenols, tannis, leucoanthocianidins, flavonoids, steroids, triterpens and alka- 
loids were performed according to Matos (2000). These tests are based on visual observation of color modification or precipitate formation after addition of specific reagents.

\section{Statistical ANALYsis}

For cytotoxicity assays, the $\mathrm{IC}_{50}$ and $\mathrm{EC}_{50}$ values and their $95 \%$ confidence intervals were obtained by nonlinear regression using the Graphpad program (Intuitive Software for Science, San Diego, CA). In order to determine differences, data (mean \pm standard error mean) were compared by analysis of variance (ANOVA) followed by Newman-Keuls test $(\mathrm{P}<0.05)$.

\section{RESULTS AND DISCUSSION}

Drug discovery from medicinal plants has played an important role in the treatment of cancer and most new clinical applications of plant secondary metabolites and their derivatives have applied towards combating cancer (Butler 2004, Cragg and Newman 2005). In this work, of the 21 ethanolic extracts tested, the analyses by MTT assay showed that only the ethanolic extract obtained from M. urundeuva seeds showed cytotoxic potential against cancer cells (Table II), given that it was the sole extract that caused cell proliferation inhibition higher than $90 \%$ (Torres et al. 2005). Subsequently, we determined its $\mathrm{IC}_{50}$ values on tumor lines by MTT assay in a similar way as described above with the bioactive extract concentration ranging from 0.09 to $50 \mu \mathrm{g} / \mathrm{mL}$. According to the American National Cancer Institute, the $\mathrm{IC}_{50}$ limit to consider a promising crude extract for further purification is a value lower than $30 \mu \mathrm{g} / \mathrm{mL}$ (Suffness and Pezzuto 1990). As seen in Table III, EEMUS was inactive against in vitro colon and melanoma tumors, while it demonstrated moderate activity on glioblastoma [SF-295, $\mathrm{IC}_{50}$ of $25.1(17.3 .3-36.3) \mu \mathrm{g} / \mathrm{mL}$ ] and especially on leukemia [HL-60, $\mathrm{IC}_{50}$ of 12.5 (9.516.7) $\mu \mathrm{g} / \mathrm{mL}$ ] cells. On the other hand, the positive control doxorubicin presented high cytotoxicity against all cell lines (Table III).

Myracrodruon urundeuva Fr. Allemao, 1881 (Anarcadiaceae), an endemic tree in Northeastern Caatinga, is a folk medicinal plant known as "aroeira do sertão" very used for treating bleeding gums and gynecological disorders (Viana et al. 2003, Monteiro et al. 2006). Different parts of M. urundeuva also possess hepatoprotective, anti-diarrheal, anti-ulcer, cicatrizing, colonic anastomotic wound healing properties and larvicidal activity (Viana et al. 2003, Goes et al. 2005, Souza et al. 2007, Sá et al. 2009). Recently, Sá et al. (2008) isolated a termiticidal lectin from M. urundeuva heartwood resistant to enzyme degradation to elucidate the resistance and durability of its wood to biodegradation by termites, a plague that has caused damages in several wooden parts in buildings and serious economical issues. Despite its diverse pharmacological applications, this is the first study showing a directed anticancer potentiality of this plant.

In an attempt to envisage an antitumor action upon in vivo assessments, it was determined the EEMUS activity on Sarcoma 180 cells using the Alamar Blue assay. Here, we also found antiproliferative action of EEMUS against these malignant cells, exhibiting an $\mathrm{IC}_{50}$ of 38.1 (33.5-43.4) $\mu \mathrm{g} / \mathrm{mL}$, an additional findings that stimulates further investigation to understand its mechanism of action.

Cell type antiproliferative specificity is observed in some plant extracts and this is probably due to the presence of different classes of compounds (Cragg et al. 1994). Hence, the use of more than one cell line is considered necessary for detection of cytotoxic compounds. In the present work, EEMUS showed activity against leukemia line 2-fold higher than against melanoma and Sarcoma 180 cells $(\mathrm{P}<0.05)$. Then, we chose the HL60 line to study underlying mechanisms involved in the in vitro cytotoxicity. The human HL-60 cell line, acute promyelocytic leukemia with prevailing of neuthophilic promyelocytes, is commonly used in the research for novel cytotoxic substances (Costa et al. 2008, Ferreira et al. 2010, Magalhães et al. 2010).

Extract-induced morphological alterations in HL60 treated and untreated cells were examined following $72 \mathrm{~h}$ of treatment and staining by H\&E. In comparison with the control cells and treated cells at the lowest concentration $(6.25 \mu \mathrm{g} / \mathrm{mL})$, both exhibiting a typical non-adherent morphology and dividing cells (Fig. 1A), EEMUS-treated cells at $12.5 \mu \mathrm{g} / \mathrm{mL}$ presented chromatin condensation and shrinking (Fig. 1D) while damage on plasmatic membrane was mainly seen at $25 \mu \mathrm{g} / \mathrm{mL}$ (Fig. 1E). Doxorubicin also induced reduction in cell volume, besides nuclear disintegration and chromatin condensation (Fig. 1B). 
TABLE II

Tumor cell proliferation inhibition (\%) of ethanolic seed extracts of twenty-one plant species belonging to different families from Northeastern Brazil determined by MTT assay after 72h of incubation at the concentration of $50 \mu \mathrm{g} / \mathrm{mL}$.

\begin{tabular}{l|c|c|c|c}
\hline \multirow{2}{*}{\multicolumn{1}{c}{ Substance }} & \multicolumn{4}{|c}{ Cell proliferation inhibition (\%) } \\
\cline { 2 - 5 } & HCT-8 & SF-295 & $\begin{array}{c}\text { MDA/ } \\
\text { MB-435 }\end{array}$ & HL-60 \\
\hline Myracrodruon urundeuva & $69.2 \pm 0.8$ & $101.7 \pm 1.4$ & $17.2 \pm 0.3$ & $100.2 \pm 0.4$ \\
\hline Schinopsis brasiliensis & $16.7 \pm 12.7$ & $22.5 \pm 1.9$ & $-21.9 \pm 5.8$ & $-15.8 \pm 16.7$ \\
\hline Caryocar coriaceum & $8.5 \pm 5.9$ & $19.6 \pm 1.5$ & $-3.2 \pm 8.7$ & $23.9 \pm 9.8$ \\
\hline Licania tomentosa & $3.0 \pm 12.7$ & $11.7 \pm 2.6$ & $32.5 \pm 0.2$ & $-5.9 \pm 0.1$ \\
\hline Licania rigida & $21.6 \pm 3.5$ & $29.5 \pm 0.2$ & $40.0 \pm 7.3$ & $67.9 \pm 16.3$ \\
\hline Connarus detersus & $6.5 \pm 4.2$ & $23.2 \pm 3.5$ & $6.4 \pm 5.0$ & $-29.2 \pm 20.3$ \\
\hline Adenanthera pavonina & $30.8 \pm 5.2$ & $23.7 \pm 3.2$ & $4.5 \pm 2.4$ & $1.2 \pm 13.2$ \\
\hline Amburana cearensis & $12.8 \pm 3.8$ & $29.0 \pm 2.8$ & $2.1 \pm 10.8$ & $16.6 \pm 0.1$ \\
\hline Anadenanthera macrocarpa & $5.5 \pm 6.8$ & $23.1 \pm 1.9$ & $-4.7 \pm 1.3$ & $-37.2 \pm 7.0$ \\
\hline Dioclea megacarpa & $-0.8 \pm 2.2$ & $29.1 \pm 1.6$ & $8.8 \pm 0.6$ & $1.7 \pm 6.6$ \\
\hline Enterolobium contortisiliquum & $-5.9 \pm 3.0$ & $36.0 \pm 1.2$ & $12.6 \pm 3.8$ & $-33.3 \pm 4.2$ \\
\hline Hymenaea courbaril & $30.9 \pm 1.0$ & $27.5 \pm 1.3$ & $7.9 \pm 1.0$ & $68.4 \pm 6.4$ \\
\hline Lonchocarpus sericeus & $11.0 \pm 3.5$ & $43.0 \pm 0.1$ & $22.3 \pm 10.9$ & $-16.9 \pm 2.7$ \\
\hline Luetzelburgia auriculata & $-1.1 \pm 0.1$ & $24.3 \pm 7.3$ & $3.0 \pm 7.3$ & $-25.5 \pm 6.1$ \\
\hline Parkia platycephala & $27.4 \pm 5.7$ & $27.5 \pm 3.9$ & $0.7 \pm 3.3$ & $-3.7 \pm 5.8$ \\
\hline Piptadenia moniliformis & $12.3 \pm 5.7$ & $30.6 \pm 0.6$ & $-15.7 \pm 2.1$ & $0.8 \pm 7.7$ \\
\hline Senna obtusifolia & $18.6 \pm 0.5$ & $33.5 \pm 1.9$ & $-3.2 \pm 3.2$ & $14.8 \pm 26.3$ \\
\hline Triplaris gardneriana & $12.6 \pm 0.4$ & $34.6 \pm 0.2$ & $10.9 \pm 9.3$ & $5.3 \pm 0.7$ \\
\hline Ziziphus joazeiro & $-22.0 \pm 4.6$ & $25.3 \pm 6.5$ & $12.3 \pm 4.5$ & $-9.9 \pm 0.6$ \\
\hline Talisia esculenta & $-0.9 \pm 3.9$ & $25.2 \pm 2.5$ & $16.7 \pm 3.4$ & $-22.4 \pm 4.4$ \\
\hline Sapindus saponaria & $-2.1 \pm 5.7$ & $23.6 \pm 3.6$ & $-2.1 \pm 1.4$ & $-15.8 \pm 16.7$ \\
\hline Doxorubicin & $89.6 \pm 0.6$ & $98.3 \pm 2.5$ & $99.1 \pm 2.2$ & $97.2 \pm 1.1$ \\
\hline & & & & \\
\hline
\end{tabular}

*Results are expressed as mean \pm standard error mean (S.E.M.) from two independent experiments for leukemia (HL-60), melanona (MDA/MB-435), glioblastoma (SF-295) and colon (HCT-8) human cancer cells. All cell lines were plated with RPMI 1640 medium supplemented with $10 \%$ fetal bovine serum, $2 \mathrm{mM}$ glutamine, $100 \mathrm{U} / \mathrm{mL}$ penincillin and $100 \mu \mathrm{g} / \mathrm{mL}$ streptomycin, at $37^{\circ} \mathrm{C}$ with $5 \% \mathrm{CO}_{2}$. Doxorubicin $(0.3 \mu \mathrm{g} / \mathrm{mL})$ was used as positive control.

TABLE III

In vitro cytotoxic activity of the ethanolic extract of Myracrodruon urundeuva seeds (EEMUS) against human tumor cell lines determined by MTT assay after $72 \mathrm{~h}$ exposure.

\begin{tabular}{c|c|c|c|c}
\hline \multirow{2}{*}{ Substance } & \multicolumn{4}{|c}{$\mathrm{IC}_{50}(\mu \mathrm{g} / \mathrm{mL})^{*}$} \\
\cline { 2 - 5 } & HL-60 & MDA/MB-435 & SF-295 & HCT-8 \\
\hline \multirow{2}{*}{ Doxorubicin } & 0.02 & 0.48 & 0.23 & 0.01 \\
& $0.01-02$ & $0.34-0.66$ & $0.19-0.25$ & $0.01-0.02$ \\
\hline \multirow{2}{*}{ EEMUS } & 12.5 & $>50$ & 25.1 & $>50$ \\
& $9.5-16.7$ & & $17.3-36.3$ & \\
\hline
\end{tabular}

*Data are presented as $\mathrm{IC}_{50}$ values and $95 \%$ confidence intervals for leukemia (HL60), melanoma (MDA/MB-435), glioblastoma (SF-295) and colon (HCT-8) cells. All cell lines were plated with RPMI 1640 medium supplemented with $10 \%$ fetal bovine serum, $2 \mathrm{mM}$ glutamine, $100 \mathrm{U} / \mathrm{mL}$ penincillin and $100 \mu \mathrm{g} / \mathrm{mL}$ streptomycin, at $37^{\circ} \mathrm{C}$ with $5 \% \mathrm{CO}_{2}$. Doxorubicin $(0.009-5 \mu \mathrm{g} / \mathrm{mL})$ was used as positive control. Independent experiments were performed in triplicate. 

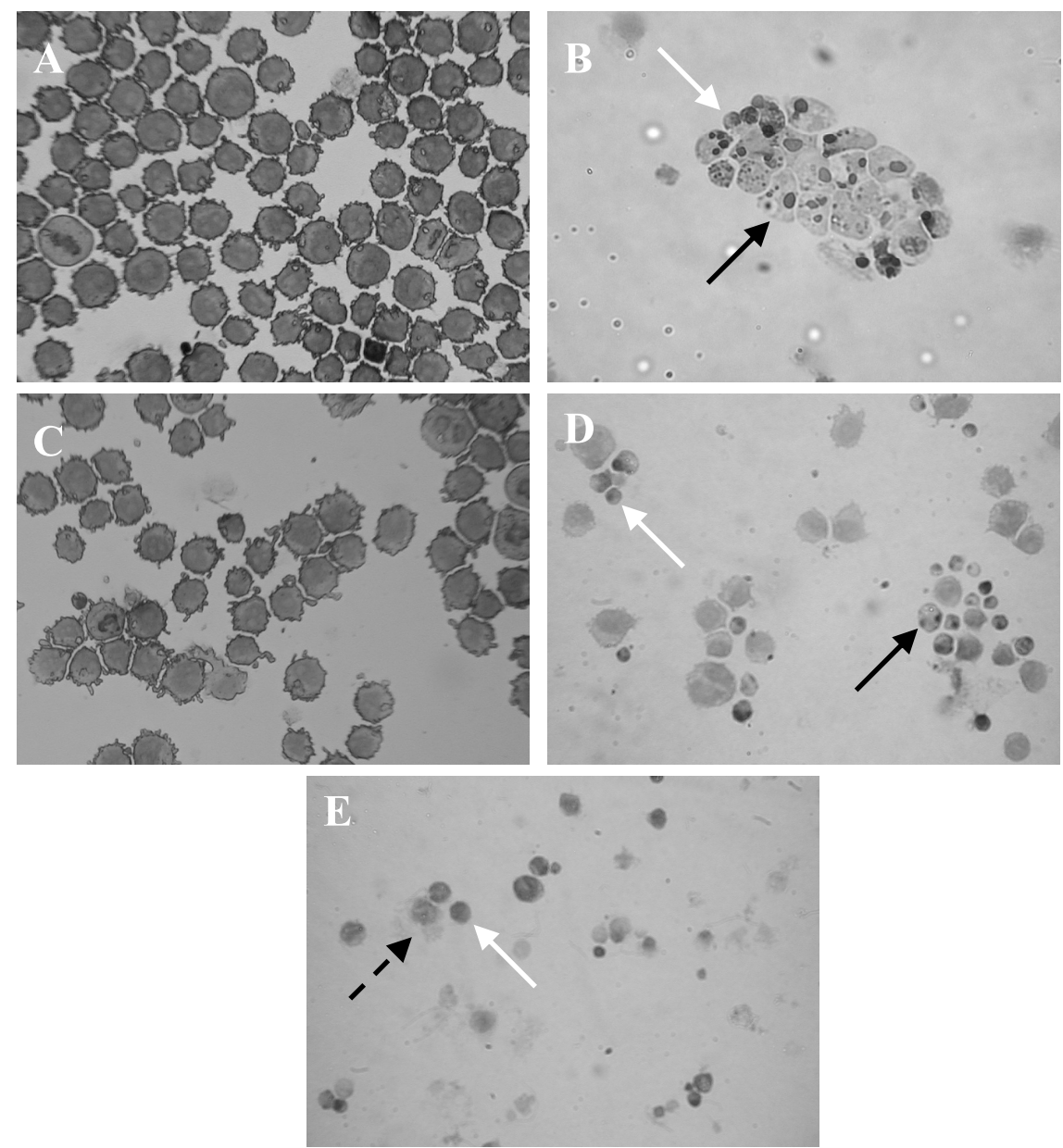

Fig. 1 - Morphological analysis of 72 h-untreated (A) or treated leukemia HL-60 cells with ethanolic extract of Myracrondruon urundeuva seeds (EEMUS) 6.25 (C), 12.5 (D) and $25 \mu \mathrm{g} / \mathrm{mL}$ (E), stained by Hematoxylin-Eosin (H\&E) and examined by light microscopy. Doxorubicin $(0.3 \mu \mathrm{g} / \mathrm{mL})$ was used as positive control (B). Negative control (A) was treated with the vehicle used for diluting the tested substance. Black arrows: chromatin condensation; white arrows: cell volume reduction; black dashed arrow: plasmatic membrane disruption. Magnification, $400 \times$.

Growth-inhibitory effects of the EEMUS were also analyzed in HL-60-treated cells by flow cytometry. The propidium iodide intercalation test showed that EEMUS caused a decreasing in the cell number in a dose-dependent manner after $72 \mathrm{~h}$ of exposure (Fig. 2A), starting at the concentration of $12.5 \mu \mathrm{g} / \mathrm{mL}$ ( $\mathrm{IC}_{50}$ value). These results are consistent with the MTT findings and with reduction of cell viability (Fig. 2B) at $25 \mu \mathrm{g} / \mathrm{mL}$ $(71.9 \pm 2.4 \%)$ in comparison to the negative control $(95.1 \pm 1.1 \%)(\mathrm{P}<0.01)$. Internucleosomal DNA evaluations showed that EEMUS led to a significant and dosedependent increase in the DNA fragmentation $(\mathrm{P}<0.01)$, with fragmentation percentages of $27.7 \pm 2.4 \%$ and $45.5 \pm 2.0 \%$, for the concentrations of 12.5 and $25 \mu \mathrm{g} /$
$\mathrm{mL}$, respectively (Fig. 3). On the other hand, statistically significant cellular mitochondrial depolarization (Fig. 2B) was detected only at the highest concentration 27.6 $\pm 4.5 \%(\mathrm{P}<0.01)$, suggesting that cell death should be initially triggered by a mitochondrial independent pathway or it could be an apoptosis resulting from an early DNA fragmentation (Wang et al. 1999).

Morphological and flow cytometric studies revealed a concomitant deoxyribonucleic acid disintegration (increasing sub-G1 population cells), chromatin condensation with membrane integrity at $12.5 \mu \mathrm{g} / \mathrm{mL}$ and membrane disruption at higher concentrations. These results suggest dose-dependent apoptotic cell death activation by EEMUS, though other biochemical and 
A
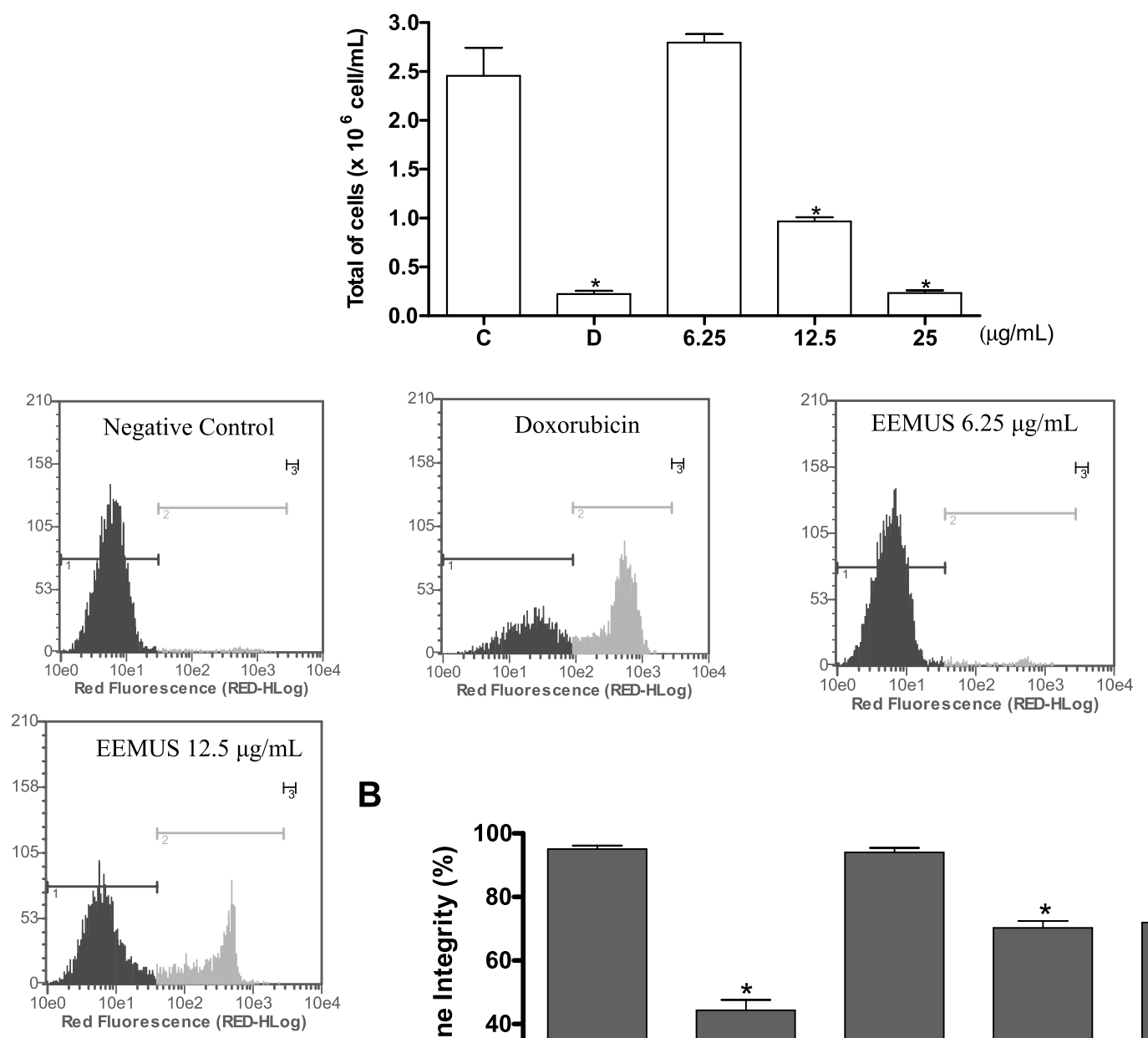

B
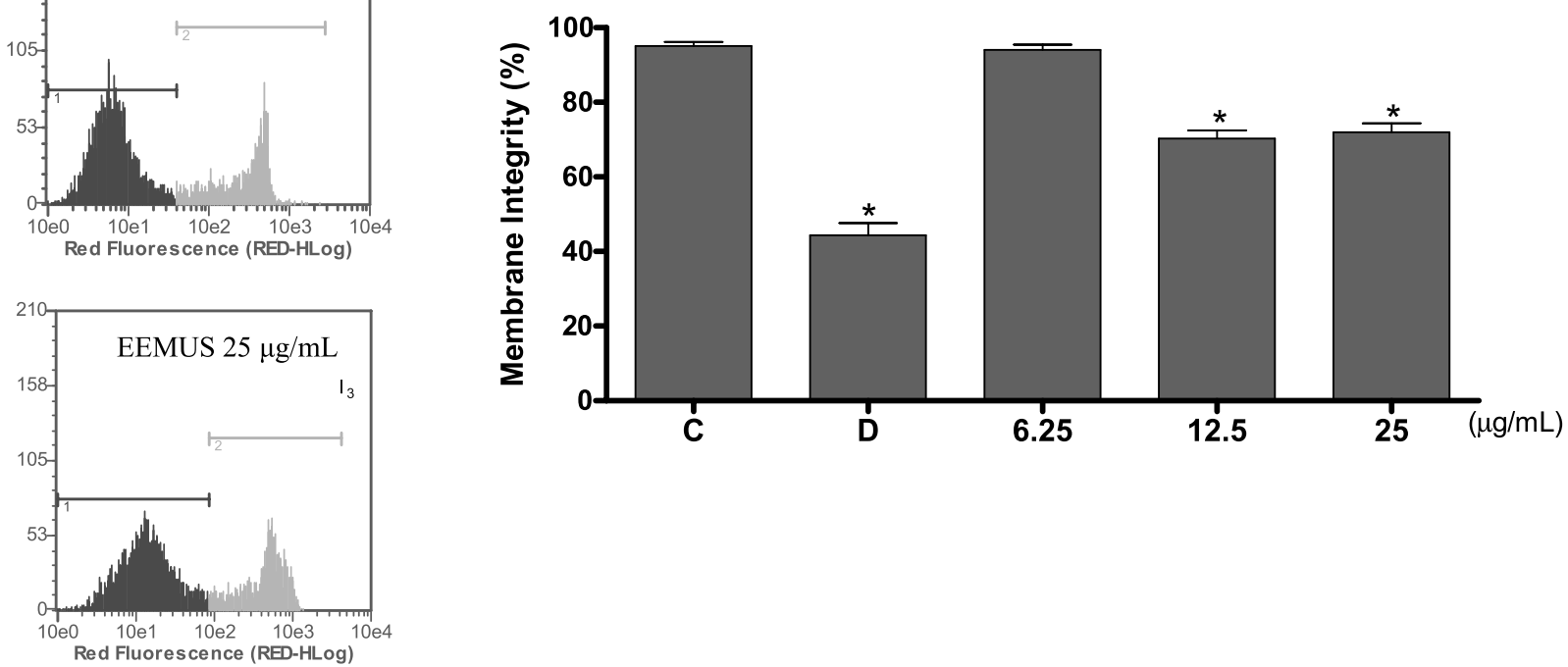

Fig. 2 - Effects of the ethanolic extract of Myracrodruon urundeuva seeds (EEMUS) on HL-60 cells analyzed by flow cytometry after $72 \mathrm{~h}$ exposure. A - Total of cells; B - Cell membrane integrity. Analyses were determined by exclusion of propidium iodide. Negative control (C) was treated with the vehicle used to dilute the tested substance. Doxorubicin $(0.3 \mu \mathrm{g} / \mathrm{mL})$ was used as positive control (D). Results are expressed as mean \pm standard error of measurement (S.E.M.) from three independent experiments. ${ }^{*} \mathrm{P}<0.01$ compared to control by ANOVA followed by Student Newman-Keuls test.

morphological examinations are necessary to confirm it, such as phosphatidylserine externalization and caspase determinations (Strasser et al. 2000).

The phytochemical analyses detected the presence of steroids, alkaloids and phenols in EEMUS (data not shown). Some steroids, flavonoids and other phenolic substances are frequently associated with the aging process of the human body, production of free radicals due 

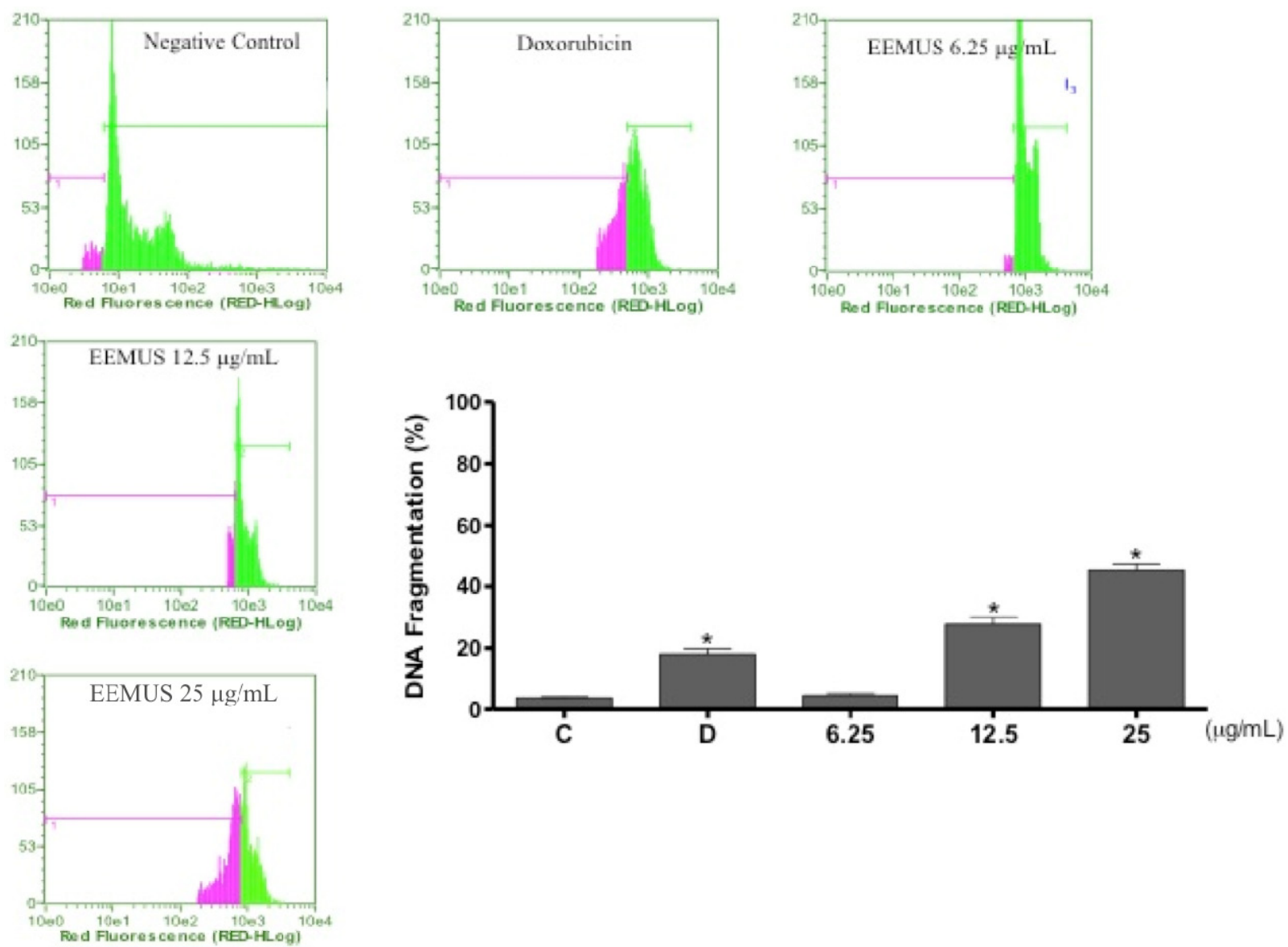

Fig. 3 - DNA fragmentation on HL-60 cells determined by flow cytometry after $72 \mathrm{~h}$ of incubation with ethanolic extract of Myracrodruon urundeuva seeds (EEMUS). All evaluations were performed by nuclear fluorescence using propidium iodide, triton X-100 and citrate. Negative control (C) was treated with the vehicle used for diluting the tested substance. Doxorubicin $(0.3 \mu \mathrm{g} / \mathrm{mL})$ was used as positive control (D). Results are expressed as mean \pm standard error of measurement (S.E.M.) from three independent experiments. ${ }^{*} \mathrm{P}<0.01$ compared to control by ANOVA followed by Student Newman-Keuls test.

to metabolic processes, initiation and promotion of cancer and tissue injury by free radicals, which has induced the intake of antioxidant products as chemical factors that prevent the onset of diseases (Núñez-Sellés 2005). Previously, it was demonstrated that hydroalchoolic stem bark extracts from M. urundeuva exert anti-inflammatory effects attributed to chalcones (Viana et al. 2003, Souza et al. 2007), a compound belonging to the group of flavonoids naturally found in fruits, flowers, vegetables, teas and wines (Abdulla and Gruber 2000, Ferreira et al. 2008). Besides the traditional antioxidant properties attributed to the flavonoids, some chalcones and their derivatives have reported to be potent cyclooxygenase inhibitors (Hsieh et al. 1998). This is an important approach to some kinds of cancers, since COX-2 blockage avoids the expression of NF- $\kappa \mathrm{B}$ activation, a key nuclear transcription factor involved in controlling inflammation and tumorigenesis (Surh et al. 2001), since inflammation has been frequently found in premalignant lesions (Dranoff 2004).

This study displays the antiproliferative action of the ethanolic extract of Myracrondruon urundeuva seeds on leukemia cells by death suggestive of apoptosis and also showed its potential against experimental in vivo tumors. Further studies to support these discoveries are in progress as well as phytochemical and molecular investigations to identify the bioactive compound(s) responsible for this cytotoxic activity. 


\section{ACKNOWLEDGMENTS}

We wish to thank Conselho Nacional de Desenvolvimento Científico e Tecnológico (CNPq), Coordenação de Aperfeiçoamento de Pessoal de Nível Superior (CAPES), Fundação Cearense de Apoio ao Desenvolvimento Científico e Tecnológico (FUNCAP), Financiadora de Estudos e Projetos (FINEP) and Banco do Nordeste do Brasil (BNB) for financial support in the form of grants and fellowship awards. We are grateful to Berenice Alves and Silvana França dos Santos for technical assistance.

\section{RESUMO}

Este estudo avaliou o potencial antiproliferativo e citotóxico contra linhagens de células tumorais de extratos etanólicos de sementes de vinte e uma espécies vegetais pertencentes a diferentes famílias do Nordeste brasileiro. Além disso, alguns mecanismos subjacentes envolvidos nesta citotoxidade também foram investigados. Dentre os 21 extratos testados pelo ensaio do MTT após $72 \mathrm{~h}$ de incubação, apenas o extrato etanólico obtido a partir de sementes de Myracrodruon urundeuva (EEMUS), o qual apresentou traços de esteróides, alcalóides e fenóis em sua composição, demonstrou atividade citotóxica in vitro contra células tumorais humanas, sendo 2 vezes mais ativo sobre a linhagem leucêmica HL-60 [ IC $_{50}$ valor de $12,5(9,5-16,7) \mu \mathrm{g} / \mathrm{mL}]$ do que sobre células de glioblastoma SF-295 [IC 50 de 25,1 (17,3-36,3) $\mu \mathrm{g} / \mathrm{mL}$ ] e de sarcoma 180 [ $\mathrm{IC}_{50}$ de 38,1 $\left.(33,5-43,4) \mu \mathrm{g} / \mathrm{mL}\right]$. Após $72 \mathrm{~h}$ de exposição, as análises morfológicas e por citometria de fluxo de células HL-60 tratadas com EEMUS mostraram diminuição no número de células, seu volume e viabilidade, assim como fragmentação internucleosomal do DNA de forma dose-dependente, sugerindo que a ação antiproliferativa de EEMUS pode ser ativada por vias apoptóticas.

Palavras-chave: potencial antiproliferativo, plantas do Nordeste Brasileiro, Myracrodruon urundeuva, tumor sarcoma 180, Extratos de sementes.

\section{REFERENCES}

Abdulla M And GRUber P. 2000. Role of diet modification in cancer prevention. Biofactors 12: 45-51.

Albiero ALM, Sertié JAA And BACCHi EM. 2008. Antiulcer activity of Sapindus saponaria L. in the rat. J Ethnopharmacol 82: 41-44.

Alencar NM, CAVAlCANTE CF, VAsconcelos MP, Leite KB, Aragão KS, Assreuy AM, Nogueira
NA, CAVADA BS AND VALE MR. 2005. Anti-inflammatory and antimicrobial effect of lectin from Lonchocarpus sericeus seeds in an experimental rat model of infectious peritonitis. J Pharm Pharmacol 57: 919-922.

Alviano WS, Alviano DS, Diniz CG, Antoniolli AR, Alviano CS, Farias LM, Carvalho MA, Souza MM AND BOLOGNESE AM. 2008. In vitro antioxidant potential of medicinal plant extracts and their activities against oral bacteria based on Brazilian folk medicine. Arch Oral Biol 53: 545-552.

Botelho MA, Rao VS, Carvalho CB, Bezerra-Filho JG, Fonseca SG, Vale ML, Montenegro D, CUNHA F, RiBEIRO RA AND BRITO GA. 2007. Lippia sidoides and Myracrodruon urundeuva gel prevents alveolar bone resorption in experimental periodontitis in rats. J Ethnopharmacol 113: 471-478.

BRAGA FC, WAGNer H, LOMBARd JA AND DE OLIVEIRA AB. 2000. Screening Brazilian plant species for in vitro inhibition of 5-lipoxygenase. Phytomed 6: 447-452.

BURIOL L ET AL. 2009. Composição química e atividade biológica de extrato oleoso de própolis: uma alternativa ao extrato etanólico. Quim nova 32: 296-302.

BUTLER MS. 2004. The role of natural product chemistry in drug discovery. J Nat Prod 67: 2141-2153.

CAstro-FARIA-Neto HC ET AL. 1991. Pro-inflammatory activity of enterolobin: a haemolytic protein purified from seeds of the Brazilian Tree Enterolobium contortisiliquum. Toxicon 29: 1143-1150.

Costa PM, FERreira PMP, Bolzani VS, Furlan M, Santos VAFFM, Corsino J, Moraes MO, CostaLotufo LV, Montenegro RC And Pessoa C. 2008. Antiproliferative activity of pristimerin isolated from Maytenus ilicifolia (Celastraceae) in human HL-60 cells. Toxicol in vitro 22: 854-863.

Costa-Lotufo LV et AL. 2003. Antiproliferative effects of several compounds isolated from Amburana cearensis A. C. Smith. Z. Naturforsch. [C] 58: 675-680.

Cragg GM, Boyd MR, Cardellina JH, Newman DJ, SNADER KM AND MCClOUd TG. 1994. Ethnobotany and drug discovery experience of the US National Cancer Institute. In: CHADWICK DJ AND MARSH J (Eds), Ciba Foundation Ethnobotany and the search for new drugs. Chichester: J Wiley \& Sons, p. 178-196.

CRAGg GM AND NEWMAN DJ. 2005. Plants as a source of anti-cancer agents. J Ethnopharmacol 100: 72-79.

Cruz mC, Santos Po, Barbosa AMJr, de Melo DL, Alviano CS, Antoniolli AR, Alviano DS AND TRINDADE RC. 2007. Antifungal activity of Brazilian medicinal plants involved in popular treatment 
of mycoses. J Ethnopharmacol 111: 409-412.

Cunha GM, Fontenele JB, Nobre-Júnior HV, de Sousa FC, Silveira ER, Nogueira NA, Moraes MO, Viana GS And Costa-Lotufo LV. 2003. Cytotoxic activity of chalcones isolated from Lonchocarpus sericeus (Pocr.) Kunth. Phytother Res 17: 155-159.

Cury-Boaventura MF, Pompéia C ANd Curi R. 2003. Comparative toxicity of oleic acid and linoleic acid on Jurkat cells. Clin Nutr 23: 721-732.

DARZYNKIEWICZ Z, BRUNo S, DEL Bino G, GORCZYCA W, Hotz MA, Lassota P and Traganos F. 1992. Features of apoptotic cells measured by flow cytometry. Cytometry 13: 795-808.

De Sousa MV And Morhy L. 1989. Enterolobin, a hemolytic protein from Enterolobium contortisiliquum seeds (Leguminosae - Mimosoideae). Purification and characterization. An Acad Bras Cienc 61: 405-412.

DranofF G. 2004. Cytokines in cancer pathogenesis and cancer therapy. Nature Rev Cancer 4: 11-22.

EEC Directive of 1986. Council Directive of 24 November 1986 on the approximation of laws, regulations and administrative provisions of the Member States regarding the protection of animals used for experimental and other scientific purposes $(86 / 609 / \mathrm{EEC})$.

Fernandes J, Castilho Ro, da Costa Mr, WagnerSouza K, Coelho-Kaplan MA and Gattass CR. 2003. Pentacyclic triterpenes from Chrysobalanaceae species: cytotoxicity on multidrug resistant and sensitive leukemia cell lines. Cancer Lett 190: 165-169.

Ferreira PMP, Carvalho AFU, Farias DF, CARIOLano NG, Melo VMM, Queiroz MGR, Martins AMC AND Machado-Neto JG. 2009. Larvicidal activity of the water extract of Moringa oleifera seeds against Aedes aegypti and its toxicity upon laboratory animals. An Acad Bras Cienc 81: 207-216.

FERREIRA PMP, FARIAS DF, OLIVEIRA JTA AND CARVALHO AFFU. 2008. Moringa oleifera: Bioactive compounds and nutritional potential. Rev Nutr 21: 431-437.

Ferreira PMP, Santos AG, Tininis AG, Costa PM, Cavalheiro AJ, Bolzani VS, Moraes Mo, Costa-Lotufo LV, Montenegro RC and Pessoa C. 2010. Casearin $X$ exhibits cytotoxic effects in leukemia cells triggered by apoptosis. Chem Biol Interac 188: 497-504.

Goes AC, Rodrigues LV, De Menezes DB, Grangeiro MP AND CAVAlCANTE AR. 2005. Histologic analysis of colonic anastomotic healing, in rats, under the action of 10\% Aroeira-do-sertao (Myracrodruon urundeuva Fr. All.) enema. Acta Cir Bras 20: 144-151.
HSIEH HK, LEE TH, WANG JP, WANG JJ AND LIN CN. 1998. Synthesis and anti-inflammatory effect of chalcones and related compounds. Pharm Res 15: 3946.

KINGHORN AD ET AL. 2003. Novel strategies for the discovery of plant-derived anticancer agents. Pharm Biol 41: 53-67.

Köhler I, Jenett-Siems K, Siems K, Hernández MA, IBARRA RA, BERENDSOHN WG, BIENZLE U AND EICH E. 2002. In vitro antiplasmodial investigation of medicinal plants from El Salvador. Z Naturforsch [C] 57: $277-281$.

LeAl LK, Costa MF, Pitombeira M, Barroso VM, Silveira ER, CANUTO KM AND Viana GS. 2006. Mechanisms underlying the relaxation induced by isokaempferide from Amburana cearensis in the guinea-pig isolated trachea. Life Sci 79: 98-104.

Leal LK, Fonseca FN, Pereira FA, Canuto KM, FeLipe CF, Fontenele JB, Pitombeira MV, Silveira ER AND VIANA GS. 2008. Protective effects of amburoside A, a phenol glucoside from Amburana cearensis against CCl4-induced hepatotoxicity in rats. Planta Med 74: 497-502.

Leal LK, Nechio M, Silveira ER, CAnuto KM, FonTENEle JB, Ribeiro RA And VianA GS. 2003. Antiinflammatory and smooth muscle relaxant activities of the hydroalcoholic extract and chemical constituents from Amburana cearensis A. C. Smith. Phytother Res 17: 335340.

Leal LK, Nobre-Júnior HV, Cunha GM, Moraes MO, Pessoa C, Oliveira RA, Silveira ER, CANUTO KM AND Viana GS. 2005. Amburoside A, a glucoside from Amburana cearensis, protects mesencephalic cells against 6-hydroxydopamine-induced neurotoxicity. Neurosci Lett 388: 86-90.

Lemos JR AND RodAL MJN. 2002. Fitossociologia do componente lenhoso de um trecho da vegetação de caatinga no Parque Nacional Serra da Capivara, Piauí, Brasil. Acta Bot Bras 16: 23-42.

Luna JS, Santos AF, Lima MrF, Omena MC, MenDONÇA FAC, BIEBER LW AND SANT'ANA AEG. 2005. A study of the larvicidal and molluscicidal activities of some medicinal plants from Northeast Brazil. J Ethnopharmacol 97: 199-206.

Magalhães HIF, Ferreira PMP, Moura ES, Torres MR, Alves APNN, Pessoa OdL, Costa-Lotufo LV, Moraes MO AND PessoA C. 2010. In vitro and in vivo antiproliferative activity of Calotropis procera stem extracts. An Acad Bras Cienc 82: 407-416.

MAIA GN. 2004. Caatinga: Árvores e arbustos e suas utilidades. D \& Z. Fortaleza, 413 p. 
MAtos FJA. 2000. Plantas Medicinais - guia de seleção e emprego de plantas usadas em fitoterapia no nordeste do Brasil. Imprensa Universitária. Fortaleza, $346 \mathrm{p}$.

Mimaki Y, Harada H, Sakuma C, Haraguchi M, Yui S, Kudo T, Yamazaki M and Sashida Y. 2003. Enterolosaponins A and B, novel triterpene bisdesmosides from Enterolobium contortisiliquum and evaluation for their macrophage-oriented cytotoxic activity. Bioorg Med Chem Lett 13: 623-627.

Miranda MM, Gonçalves JL, Romanos MT, Silva FP, Pinto L, Silva MH, Ejzemberg R, Granja LF AND WIgG MD. 2002. Anti-herpes simplex virus effect of a seed extract from the tropical plant Licania tomentosa (Benth.) Fritsch (Chrysobalanaceae). Phytomed 9: 641645.

Monteiro JM, Albuquerque UP, Lins-Neto EMF, ARAÚJO EL AND AMORIM ELC. 2006. Use patterns and knowledge of medicinal species among two rural communities in Brazil's semi-arid northeastern region. J Ethnopharmacol 105: 173-186.

MosmanN T. 1983. Rapid colorimetric assay for cellular growth and survival: application to proliferation and cytotoxicity assays. J Immunol Methods 16: 55-63.

Nicoletti I, Migliorati G, Pagliacci MC, Grignani F AND RICCARDI C. 1991. A rapid and simple method for measuring thymocyte apoptosis by propidium iodide staining and flow cytometry. J Immunol Methods 139: 271-279.

NúÑEZ-SELlÉS AJ. 2005. Antioxidant Therapy: Myth or Reality? J Braz Chem Soc 16: 699-710.

Olajide OA, ECHIANU CA, Adedapo AD AND MaKinDE JM. 2004. Anti-inflammatory studies on Adenanthera pavonina seed extract. Inflammopharmacol 12: 196-202.

Rodrigues LV, Ferreira FV, Regadas FS, Matos D AND VIANA GS. 2002. Morphologic and morphometric analyses of acetic acid-induced colitis in rats after treatment with enemas from Myracrodruon urundeuva Fr. All. (Aroeira do Sertão). Phytother Res 16: 267-272.

SÁ RA, NAPOlEão TH, SANTOS NDL, Gomes FS, AlBuQuerque AC, Xavier HS, Coelho LCBB, Bieber LW AND PAIVA PMG. 2008. Induction of mortality on Nasutitermes corniger (Isoptera, Termitidae) by Myracrodruon urundeuva heartwood lectin. Int Biodeterior Biodegrad 62: 460-464.

SÁ RA, SAntos NDL, Silva CSB, Napoleão TH, Gomes FS, CAVAda BSC, COElHo LCBB, NaVArro DMAF, BIEBER LW AND PAIVA PMG. 2009. Larvicidal activity of lectins from Myracrodruon urundeuva on Aedes aegypti. Comp. Biochem Physiol 149: 300-306.
Sampaio CA, Motta G, SAmpaio MU, Oliva ML, AraúJo MS, Stella RC, TANAKA AS AND Batista IF. 1992. Action of plant proteinase inhibitors on enzymes of the kallikrein kinin system. Agents Actions Suppl 36: 191-199.

SAMPAio EVSB. 2002. Vegetação \& Flora da Caatinga. Associação Plantas do Nordeste/Centro Nordestino de Informação sobre Plantas. Recife, p. 49-90.

Santos JP, Araújo EL AND AlbuQuerque UP. 2008. Richness and distribution of useful woody plants in the semi-arid region of northeastern Brazil. J Arid Environ 72: 652-663.

Shahat AA, El-Barouty G, Hassan RA, Hammouda FM, ABDEl-RAHMAN FH AND SALEH MA. 2008. Chemical composition and antimicrobial activities of the essential oil from the seeds of Enterolobium contortisiliquum (leguminosae). J Environ Sci Health B 43: 519-525.

Sousa MP, Matos FJA, Matos MEO, Machado MIL AND CRAVEIRO AA. 2004. Constituintes químicos ativos e propriedades biológicas de plantas medicinais brasileiras. Edições UFC. Fortaleza, 448 p.

Souza SM, Aquino LC, Milach ACJR, Bandeira MA, Nobre ME AND VianA GS. 2007. Anti-inflammatory and antiulcer properties of tannins from Myracrodruon urundeuva Allemão (Anacardiaceae) in rodents. Phytother Res 21: 220-225.

Strasser A, O'Connor L And Dixit VM. 2000. Apoptosis signaling. Annu Rev Biochem 69: 217-245.

Suffness M And Pezzuto JM. 1990. Assays related to cancer drug discovery. In: Hostettmann K (Ed), Methods in plant biochemistry: assays for bioactivity. Academic Press, London, p. 71-133.

Surh YJ, Chun KS, Cha HH, Han SS, KeUM YS, PARK KK AND LEE SS. 2001. Molecular mechanisms underlying chemopreventive activities of anti-inflammatory phytochemicals: down-regulation of COX-2 and iNOS through suppression of NF- $\kappa \mathrm{B}$ activation. Mutation Res 480-481: 243-268.

Torres Mr, Sousa APA, Filho EATS, Pessoa C, Moraes MEA, Moraes MO AND Costa-Lotufo LV. 2005. Biological activity of aqueous and organic extracts of seaweeds form Ceará, Brasil. Arq Cien Mar 38: $55-63$.

Tsuzuki JK, SVIDzinski TI, Shinobu CS, Silva LF, Rodrigues-Filho E, CORTEZ DA AND FERreirA IC. 2007. Antifungal activity of the extracts and saponins from Sapindus saponaria L. An Acad Bras Cienc 79: $577-583$. 
VianA GSB, BANDEIRA MAM AND MATOS FJA. 2003. Analgesic and antiinflammatory effects of chalcones isolated from Myracrodruon urundeuva Allemão. Phytomed 10: $189-195$.

XaVier-Filho J. 1993. Sementes e suas defesas contra insetos. Projeto multinacional de biotecnologia e alimentos. Organização dos Estados Americanos, p. 1-31.
WANG IK, LIN-SHIAU SY AND LIN JK. 1999. Induction of apoptosis by apigenin and related flavonoids through cytocrome $c$ release and activation of caspase- 9 and caspase-3 in leukaemia HL-60 cells. Eur J Cancer 35: $1517-1525$ 